\title{
Research
}

\section{Human-Nature Relationship in Mediterranean Streams: Integrating Different Types of Knowledge to Improve Water Management}

\author{
$\underline{\text { Carla Gonzalez }}^{1,2}$, Adelaide Clemente $^{2}, \underline{\text { Kurt Aagaard Nielsen }}^{3}$, Cristina Branquinho $^{2}{ }^{\text {, and }}$ \\ $\underline{\text { Rui Ferreira dos Santos }}^{1}$
}

\begin{abstract}
The social and ecological systems of Mediterranean streams are intrinsically linked as a result of long human occupation. In this region, these links vary greatly across small distances due to geomorphology, resulting in great diversity across space, which poses particular challenges for understanding and managing these systems. This demands (i) interdisciplinary integration of knowledge that focuses on the social-ecological interactions, while according due consideration to the whole; and also (ii) transdisciplinary integration, integrating lay and expert knowledge to understand local specificities. To address these needs - a focus on interactions and local knowledge - the research presented here studies the human-nature relationship in Mediterranean streams. Its main objective is to improve understanding of Mediterranean streams, but it also provides practical inputs to enhance local-level management. The study adopts an applied approach from the perspective of natural resources management. A case study was developed conducting field work on streams within the Natura 2000 site of Monfurado, Portugal—a mainly privately owned area with conflicting land uses between conservation and farming. Rivers and streams in Portugal are considered to be in very bad condition, particularly with regard to water quality. The experimental design was based, from a critical realism perspective of inter- and trans-disciplinarity, on the complementarities between methodologies from (i) the social sciences: value survey and analysis of discourse; and (ii) the natural sciences: biomonitoring and integrity biotic indexes. Results characterized the connected systems from both ecological and social points of view. They also characterized the relationship between both dimensions. We concluded that well-established riparian vegetation cover of streams is a key structural element of the human-nature relationship in the Mediterranean streams of Monfurado at several levels. The central role this structure might have in the dialog between the conflicting land uses with regard to water management is discussed, and priority targets for management are identified. The tree stratum in streams may work as a conciliation factor in the conflict between farming and conservation, as it is in the interest of both sectors to maintain it; however, the shrub stratum is effectively a source of conflict between the two perspectives and needs further work at the social-change level.
\end{abstract}

Key Words: co-evolution; ecological indicators; interdisciplinary; local knowledge; natural resource management; Portugal; social-ecological systems; transdisciplinary

\section{INTRODUCTION}

According to Portugal's Millennium Ecosystem Assessment (Pereira et al. 2004), inland waters are in the worst condition of all systems in terms of ecosystem services provision in continental Portugal. This study draws particular attention to the problem of water quality, emphasizing the fact that several rivers are heavily polluted from industrial, farming, and domestic activities, with eutrophication occurring in some basins (Pereira et al. 2004).

Furthermore, in 2007, the Portuguese National Institute for Water (INAG) classified $35.8 \%$ of their surface water monitoring stations as having "Bad" or "Very Bad" water quality status and $37.9 \%$ as "Reasonable" (SNIRH 2008). These three 
classifications indicate that water quality is not sufficient for, e.g., direct contact with water in human recreational use, nor does it allow regular reproduction of freshwater fishes in general or the existence of more sensitive species (SNIRH 2008).

Rivers in southern Portugal tend to be narrow and shallow and are characterized by highly variable intra- and inter-annual flow (mainly resulting from variable in-flowing runoff). These small rivers, commonly referred to as Mediterranean streams, are particularly variable and have a spatial and temporal dynamic equilibrium influenced by a sequence of regular and often extreme flooding and drying periods (Gasith and Resh 1999). They provide many ecological functions and ecosystem goods and services. They are a source of water, food, energy, shadow, protection, habitat, biodiversity, inspiration, and leisure (Federal Interagency Stream Restoration Working Group (FISRWG) 1998). Furthermore, they are a filter and barrier in landscapes and ecosystems and at the same time a corridor connecting lowlands and upstream areas, allowing conduction of water, energy, and matter and continuity of microclimate, animal and plant distribution, and aesthetics (FISRWG 1998).

The dynamic equilibrium existing in Mediterranean streams is achieved through ecological processes, social processes, and the interaction dynamics between them. This is the case of many landscapes in Europe, which have been shaped over long periods of time by human activity. The Mediterranean region has a very particular heterogeneity and diversity of landscapes-a mosaic - that has resulted from its particular geomorphology and very long human occupation (Blondel 2006).

This understanding of Mediterranean streams as coevolved systems is rooted in Norgaard's concept of co-evolution, defined as a process of coupled change between practices, values, and the biophysical environment by Kallis (2007). From this perspective, both materially and cognitively, humans adapt to their environments, and also change them actively and adapt to their transformations; and new environments change human practices and ideas (Kallis 2007).

The adopted co-evolutionary perspective of Mediterranean streams poses particular challenges to the understanding of ecosystems and local human communities, as they are intrinsically linked and the nature of this interaction varies greatly across small distances (along with the mosaic of landscapes), increasing the number of human-nature and other biotic interactions, and enhancing biodiversity. This characteristic-diversity across physical spacemakes the management of these ecosystems challenging.

Understanding ecosystems as a co-evolutionary whole that includes social, ecological, and economic dynamics, requires an interdisciplinary approach. Different authors have emphasized the need for integration in research methodologies and analysis of most environmental systems; the field of integrated assessment provides many examples of the added value of integration, and its importance is stressed in the literature (van der Ploeg et al. 1987, van den Bergh and Nijkamp 1991, Antunes and Santos 1999, Argent et al. 1999, Rotmans and Asselt 2001, Duraiappah 2002, Pope et al. 2004).

The literature has also underlined the need for and importance of a social and human dimension in natural resource management and of transdisciplinary integration of knowledge, i.e., integration of different complementary types of knowledge, as well as its benefits (Donovan and Puri 2004, Fielding et al. 2005, Xu et al. 2006, Kessler 2007, Ballard et al. 2008, Spash et al. 2009). Silvano et al. (2005) show local ecological knowledge is an important keystone to the design and structure of natural resource management strategies and cite several authors who report that local ecological knowledge combined with scientific information has proven useful to the management of ecosystems. Moller et al. (2004) argue that, in addition to building partnership and community consensus, the integration of scientific and traditional methods and knowledge allow local communities to critically evaluate scientific predictions in their own terms and test sustainability using their own forms of adaptive management.

At the policy level, the Water Framework Directive (WFD) draws attention to the importance of the social dimension of water management and recommends the adoption of participatory approaches, inclusive of social agents' knowledge and actions. The WFD also recommends the adoption of ecological approaches to water quality monitoring, approaching surface water management in a holistic and ecologically integrated manner, prioritizing an approach that is founded in the ecological functioning and riparian ecosystems 
integrity assessment, rather than in strictly physical-chemical parameters.

The co-evolutionary perspective adopted demands that the importance of unity and structural functioning of social-ecological systems is explicitly addressed, which requires: (i) a focus on the interactions between the systems; and (ii) consideration in the analysis of the system as whole (bigger than the sum of the parts), and as such, a new unit for the analysis, termed "human-nature aggregates," where the main focus is on the specific local relationship between human systems and ecosystems - human-nature relationship — and both are recognized as part of the same whole. It is this perspective that underpins the proposed humannature relationship analysis.

By framing the proposed approach in this way, the importance of transdisciplinary integration becomes even clearer, as the focus on specificities of local knowledge, beliefs, and use of resources cannot be addressed by expert knowledge alone.

Using the concept of co-evolution and from a natural resource management standpoint, the objective of this paper is to illustrate the contributions of a human-nature relationship analysis to surface water management at local scale in rural Mediterranean regions. In order to achieve this objective, the paper presents the ways which interaction in social and ecological dimensions can inform and improve management in the selected case study.

\section{METHODS}

To explore the ways in which interaction between social and ecological dimensions of Mediterranean rivers at the local scale can inform and improve the management of water and streams in rural systems, we adopted a critical realism perspective, i.e., we assumed that the analysis, integrating different forms of knowledge, would allow us to be closer to ontological reality (Pratschke 2003). To apply that, we adopted an inter- and trans-disciplinary approach, shedding light on complementary realities of co-evolved social-ecological systems, $\dot{i}$. e., we opted for an integration of expertise from different disciplines and as well an integration of expert and lay knowledge, in order to have a clearer vision of reality from the natural resource management point of view.
We performed an experimental design, based on the complementarities between methodologies from the social sciences and from the natural sciences. From the social sciences, a value survey and an analysis of discourse allowed detailed analysis of in-depth interviews with local people that were informal, flexible, open, and inclusive of information and variables interviewees wanted to bring in. This enabled the beginning of a bottombottom knowledge-building process, with scoping in natural resource management issues and establishment of personal links (with potential for future use in participatory processes). From the natural sciences, biomonitoring and integrity biotic indexes allowed an ecological approach to water quality and stream ecological status. This approach emphasizes the assessment of ecosystem functioning, temporal integration of pollutants present in water along time, and the biotic response to pollutants, over traditional physical-chemical punctual measures of water quality. At the same time, these methods from ecology enabled use of a dense net of sampling at low cost.

\section{Study Site}

The study area is the Monfurado site (Natura 2000 network) in Alentejo, Portugal (Fig. 1). The site was selected because it is among the richest hydrographic networks in the Alentejo, in southern Portugal, a region characterized by sub-humid Mediterranean climate and dominated by cork-oak (Quercus suber) and holm-oak (Q. ilex) montado landscape. Furthermore, this is an area that experiences conflicting land uses: being a Natura 2000 Site, conservation is a priority, but most of the area (more than 95\%) is privately owned and the main socioeconomic activities are extensive cork exploitation combined with livestock production, mainly extensive and developed on a large production scale.

In this area, the pressures on stream ecological functioning are: (i) natural torrential water flow regime, (ii) diversion of water for cattle use and agriculture irrigation, (iii) change in precipitation regimes over time, (iv) pollution runoff from extensive and intensive livestock, and (v) landholders' stream management practices, (which are connected to their beliefs, values, cultural habits, and aesthetics). 
Fig. 1. Streams, sampling points, and private properties including the sampling points in the Natura 2000 Site of Monfurado located in Alentejo, Portugal.



To allow a dense net of analysis within the case study area, around 40 sampling sites were selected in the streams of Monfurado (the site's total area is 23,946 ha) (Fig. 1). The private properties existing in each sampling site were identified (Fig. 1), as well as 32 corresponding landholders.

\section{Ecological Dimension}

Water quality was assessed in the sampling sites using transplants of the bryophyte Fontinalis antipyretica Hedw., largely used as a biomonitor for water quality in freshwater ecosystems (Mersch and Reichard 1997, Vázquez et al. 1999, Cenci 2000, Figueira 2002, Martins et al. 2004). The transplants were collected from the control site at Arronches Stream in the São Mamede Mountains and placed in sampling points of the study site, using the transplanting system proposed by Cenci (2000). From September 2004 to June 2005, the transplants remained in the streams of Monfurado for periods of 3 months, after which they were immediately replaced with new transplants, fulfilling three sampling periods and covering three seasons. After collection, $3-\mathrm{cm}$ apical segments of the transplants were analyzed for their content of several pollutants: the metals copper $(\mathrm{Cu})$, zinc $(\mathrm{Zn})$, manganese $(\mathrm{Mn})$, iron $(\mathrm{Fe})$, lead $(\mathrm{Pb})$, nickel $(\mathrm{Ni})$, and arsenic (As) through atomic absorption spectrometry after acid digestion; total carbon $(\mathrm{C})$ and nitrogen $(\mathrm{N})$ by elemental analysis (EuroVector Ea3000 CHNS-O 
Element Analyzer); and ammonium $\left(\mathrm{NH}_{4}^{+}\right)$by colorimetric techniques. Finally, the vitality of transplanted mosses, an integrated estimate of the stress imposed on the organism (potentially by contaminants), was also assessed using fluorescence of chlorophyll $a$ measured after dark adaptationFv/Fm (Branquinho et al. 1997).

To assess the ecological status of streams, the information provided by biomonitors was combined with a plant-based integrity biotic index (IBI), a tool that has been increasingly used and recognized for its capacity to inform about the overall ecological condition of riparian habitats (Salinas et al. 2000, Ferreira et al. 2005, Miller et al. 2006, Reiss 2006). The IBI selected to apply in the case study was the index Qualitat del Bosc de Ribera - QBR, proposed by Munné et al. (2003) for assessing riparian habitat quality in Iberian rivers. This index ranges from 0 $-100 \%$ and is the sum of four components $(0-$ $25 \%$ ): total riparian cover (the proportion of well established vegetation in the riparian area, considered tree and shrub strata existing in the margins of streams); vegetation cover structure (the relative proportion between tree and shrub strata); cover quality (the proportion of native and nonnative species and communities considering the geomorphologic type of the river-upstream or downstream); and river channel alteration (the level of human alteration of the river channel). The index was applied in 50-m stretches of the river at each sampling site.

\section{Human Behavior Dimension}

The private properties including each sampling site were identified (Fig. 1); 32 landholders were identified for these properties. Landholders, for the purposes of this study, are defined as property owners who are active in the management of the property or, if the owner is absent, whoever is in charge of managing the farm and who has decisionmaking power regarding the daily management of the streams as well as having a high socioeconomic interest in them.

Each landholder was then contacted and interviewed in a non-structured interview using the check catalog presented in Appendix 1. This was done by using a range of open-ended questions and conversation topics that aimed to capture their values and their experiences of social, environmental, and water problems in the region as well as their visions, interpretations, and perceptions of control. The main drivers of the conversations were related to regional and national problems regarding the environment in general, water issues, and riparian systems; possible solutions for the identified set of problems; considerations about governance and social change; advantages of having riparian systems on their properties and values of these systems; conflicts resulting from common management of these resources with neighbors or other stakeholders; management practices of the streams; and finally considerations about agriculture and rural lifestyle and abandonment. The interviews were taped and then transcribed. Results illustrate landholders' values, place attachment, beliefs, aesthetics, environmental and civic awareness and visions, conceptualizations of streams, stream conservation practices, and visions of solutions/outcomes for problems identified.

\section{Data Treatment}

The data collected in the human behavior component of the analysis required a period of interpretative data treatment, described below, but the data deriving from the ecological component did not require such a procedure.

Transcriptions were initially submitted to a semiquantitative analysis to survey the values of streams to landholders in this area. The data were organized according to use/non-use, economic/non-economic, and past/current values, but the data were not monetarized. These categories are derived from the taxonomy of the total economic value framework, which systematizes in a consensually recognized and well-established framework (International Union for Conservation of Nature (IUCN) 1998, Rietbergen-McCracken and Abaza 2000) the ways in which ecosystems contribute to human wellbeing. Secondly, transcriptions were submitted to an analysis of discourse, with the support of the software NVivo 8 (QSR 2008), with the objective of characterizing qualitatively the narratives regarding: (i) environmental awareness, scoping of needs, and significance of problems for local populations; (ii) perception of control and sense of purpose in social-ecological change; (iii) place attachment and belonging; (iv) existing stream concepts; and (v) common stream conservation practices. 
Finally, these results from the human behavior dimension were compared and when possible (i.e., among quantitative data) correlated with an extensive database with all the levels of information provided by the ecological dimension of the study.

\section{RESULTS AND DISCUSSION}

The first section below presents the ecological characterization of streams in Monfurado in terms of their conservation status and levels of water pollution, i.e., ecological impacts from human activities in the area. The second section presents the social characterization of streams, detailing their social role as described by landholders. The third section explores how the social valuation of streams varies in relation to their ecological status valuation by presenting and exploring the correlations between the two sets of information. The fourth section describes the stated management practices on streams by landholders and the fifth section describes the conceptualization of streams by landholders. These two latter sections together allow the characterization of human shaping of streams in the present and their preferences and ideals for the future. The fifth section also allows an understanding of why landholders shape streams as stated in the results shown in the fourth section.

A final section synthesizes how the previous sets of information illustrate the human-nature relationship in Mediterranean streams of Monfurado and discusses its contribution to water management.

\section{The Ecological Status of Streams}

In order to characterize in general terms the condition of streams in Monfurado, Table 1 shows several statistical parameters obtained for the main ecological indicators assessed.

In the Monfurado site, no significant increase in relation to control concentrations in $\mathrm{Pb}$ and $\mathrm{Ni}$ was observed in the biomonitors. Parallel studies show $\mathrm{Fe}, \mathrm{Mn}$, and $\mathrm{Zn}$ increase with increasing sediments in the streams of Monfurado (Branquinho et al. 2007). In Monfurado streams, $\mathrm{Cu}, \mathrm{Zn}, \mathrm{As}, \mathrm{Fe}$, and $\mathrm{Mn}$ were related to land uses such as permanent agriculture, pasture, the number of cow equivalents, and septic tanks or direct domestic effluent discharges (Branquinho et al. 2007).
A low $\mathrm{C}: \mathrm{N}$ ratio indicates an excess of $\mathrm{N}$ in moss that accumulates and is not used for growth (which is indicated by $\mathrm{C}$ levels), so low $\mathrm{C}: \mathrm{N}$ indicates an excess of $\mathrm{N}$ levels and potential eutrophication. Most areas of Monfurado present problems of eutrophication, which are connected to a high level of farm development and cattle exploitation, as well as to effluents from the populated areas (Branquinho et al. 2007). It is possible to see the total average of $\mathrm{NH}_{4}{ }^{+}$for the streams in Monfurado is considerably higher than the values presented in the control site (Table 1), which signals an enrichment of this form of $\mathrm{N}$ and eutrophication problems in the streams in Monfurado.

The plant-based IBI QBR shows average values for Monfurado of $68 \%$, indicating an overall satisfactory status of conservation. The Total Riparian Cover is the sub-component of the QBR showing the lowest values overall, with an average and median of 10 out of 25 , revealing the existence of many streams with little or no well-established vegetation cover and in early stages of succession. The channel alteration shows streams are not very artificially modified in the area and the streams still have some space and structure to resist, mitigate, adapt, and change according to natural dynamics. Cover structure indicates an overall equilibrium and quality in the relative distribution of shrub and tree strata in the riparian forest area, with average 18 and median 20 out of 25 . Finally, cover quality shows high values overall, indicating a high number of native species present, with average of 18 and median of 23 out of 25 .

\section{The Social Role of Streams}

As shown in Figs. 2 and 3, over recent decades (3050 years, according to the questions in Appendix 1) there has been a transition in the way riparian systems have been used by people. Local populations were previously more dependent on riparian systems, which supplied basic needs like food provision (provision of water for human consumption, irrigation for subsistence agriculture or fishing) and personal hygiene (washing clothes and bathing). Nowadays, riparian systems are equally structuring, but in diverse ways: they are connected to the current main economic activity (extensive livestock production), contributing to this activity as water source for reservoirs, direct water source, and shading and microclimate, which protects animals during the summer (riparian forests 
Table 1. Size of the sample $(N)$, Mean, Standard Deviation (SD), Median, Minimum, Maximum Values and Values in the Control for (i) the pollutants measured in the biomonitor: copper $(\mathrm{Cu})(\mu \mathrm{g} / \mathrm{g} \mathrm{DW})$, zinc (Zn) $(\mu \mathrm{g} / \mathrm{g} \mathrm{DW})$, manganese $(\mathrm{Mn})(\mu \mathrm{g} / \mathrm{g} \mathrm{DW})$, iron $(\mathrm{Fe})(\mu \mathrm{g} / \mathrm{g} \mathrm{DW})$, lead $(\mathrm{Pb})(\mu \mathrm{g} / \mathrm{g} \mathrm{DW})$, nickel $(\mathrm{Ni})(\mu$ $\mathrm{g} / \mathrm{g} \mathrm{DW})$, arsenic (As) $(\mu \mathrm{g} / \mathrm{g} \mathrm{DW})$, total nitrogen $(\mathrm{N})(\% / \mathrm{DW})$, the ratio between total carbon and total nitrogen $(\mathrm{C}: \mathrm{N})$, ammonium $\left(\mathrm{NH}_{4}^{+}\right)(\mu \mathrm{g} / \mathrm{g} \mathrm{DW})$; (ii) vitality indicator of the mosses measured by $\mathrm{Fv} / \mathrm{Fm}$ in relation to the values in the control per season (\%); and (iii) the QBR index total score (QBR Total) (\%) and its four components $(\mathrm{TRC}=$ total riparian cover, $\mathrm{CS}=$ cover structure, $\mathrm{CQ}=$ cover quality, and $\mathrm{CA}=$ channel alteration; ranging from $0-25 \%)$.

\begin{tabular}{|c|c|c|c|c|c|c|c|}
\hline & $N$ & Mean & SD & Median & Minimum & Maximum & Control \\
\hline \multicolumn{8}{|c|}{ Metal pollutant concentrations in the moss } \\
\hline $\mathrm{Cu}(\mu \mathrm{g} / \mathrm{g} \mathrm{DW})^{\mathrm{a}}$ & 39 & 13.91 & 8.65 & 12.16 & 5.856 & 56.70 & 9.60 \\
\hline $\mathrm{Zn}(\mu \mathrm{g} / \mathrm{g} D W)^{\mathrm{a}}$ & 39 & 65.55 & 37.08 & 53.07 & 28.105 & 253.15 & 44.00 \\
\hline $\operatorname{Mn}(\mu \mathrm{g} / \mathrm{g} D W)^{a}$ & 38 & 6405.94 & 5557.05 & 5115.13 & 206.091 & 24098.35 & - \\
\hline $\mathrm{Fe}(\mu \mathrm{g} / \mathrm{g} \mathrm{DW})^{\mathrm{a}}$ & 39 & 21019.99 & 12185.93 & 17070.35 & 6684.753 & 61639.08 & 7719.71 \\
\hline $\mathrm{Pb}(\mu \mathrm{g} / \mathrm{g} \mathrm{DW})^{\mathrm{a}}$ & 38 & 1.40 & 0.86 & 1.21 & 0.110 & 3.36 & 1.04 \\
\hline $\mathrm{Ni}(\mu \mathrm{g} / \mathrm{g} \mathrm{DW})^{\mathrm{a}}$ & 9 & 0.69 & 0.23 & 0.69 & 0.327 & 1.08 & 17.20 \\
\hline As $(\mu \mathrm{g} / \mathrm{g} \text { DW })^{\text {a }}$ & 39 & 18.07 & 16.82 & 11.10 & 2.700 & 74.78 & 5.09 \\
\hline \multicolumn{8}{|c|}{ Eutrophication indicators measured in the moss } \\
\hline $\mathrm{N}(\% / \mathrm{DW})^{\mathrm{a}}$ & 39 & 2.29 & 0.47 & 2.37 & 1.172 & 3.48 & 2.52 \\
\hline $\mathrm{C}: \mathrm{N}^{\mathrm{a}}$ & 39 & 15.00 & 3.24 & 14.91 & 8.711 & 26.35 & 16.98 \\
\hline $\mathrm{NH}_{4}^{+}(\mu \mathrm{g} / \mathrm{g} \mathrm{DW})^{\mathrm{b}}$ & 9 & 113.93 & 96.74 & 97.56 & 30.000 & 341.46 & 75.67 \\
\hline \multicolumn{8}{|c|}{ Vitality indicator of the moss } \\
\hline $\mathrm{Fv} / \mathrm{Fm}(\%)^{\mathrm{a}}$ & 37 & 77.25 & 25.93 & 86.58 & 0.000 & 105.03 & n.a \\
\hline \multicolumn{8}{|c|}{ Integrity Biotic Index of the stretches of the stream } \\
\hline QBR Total $(\%)^{\mathrm{c}}$ & 39 & 68 & 20 & 70 & 20 & 100 & 80 \\
\hline $\operatorname{TRC}(0-25 \%)^{\mathrm{c}}$ & 39 & 10 & 8 & 10 & 0 & 25 & 15 \\
\hline $\operatorname{CS}(0-25 \%)^{\mathrm{c}}$ & 39 & 18 & 7 & 20 & 3 & 25 & 25 \\
\hline $\mathrm{CQ}(0-25 \%)^{\mathrm{c}}$ & 39 & 18 & 9 & 23 & 0 & 25 & 25 \\
\hline $\mathrm{CA}(0-25 \%)^{\mathrm{c}}$ & 39 & 21 & 6 & 25 & 5 & 25 & 15 \\
\hline
\end{tabular}

a average values for the time period from September 2004 to June 2005.

${ }^{\mathrm{b}}$ values assessed from March to June 2005.

${ }^{c}$ values assessed from March to June 2006. 
are used in this way). Moreover, riparian systems are currently valued for activities related to leisure and hunting, as well as for their existence (conservationist values) and for their beauty (aesthetic values). Finally, it is also interesting to note that in the current uses of streams, the scientific use of streams appears to be relevant to landholders.

Fishing and water for human consumption uses have decreased over time. This could be related to the increase in artificial surface water retention, small reservoirs, which cause low water flow in general and may increase the xeric period in streams (meaning streams tend to have more months per year with no water flow at all). Another reason could be the increase in aquatic pollution, frequently cited by landholders, resulting from higher anthropogenic pressures and aggravated by pollutant concentrations associated with the cited lower water flow, which can also impact both uses. Furthermore, the decrease in human consumption of water from streams might be associated with better living conditions, e.g., piped water in dwellings and access to bottled water.

\section{Ecological Status and Social Role of Streams}

To explore how the ecological valuation and the social valuation of streams relate to one another, Pearson correlations between the two sets of information are presented in Table 2.

Results show interesting correlations between (i) use values and economic values and (ii) QBR total score, total riparian cover (the proportion of established vegetation cover - tree and shrub strata) and cover structure (the relative proportion of tree and shrub strata) (Table 2).

Among the variables listed, the best correlation coefficients (R) are between: (i) the use values identified by the landholders and the total riparian cover, and (ii) the use values relevant to the economic activities developed, termed economic use values, and total riparian cover (Fig. 4).

The relationships in Fig. 4 make it evident that landholders using streams with higher riparian cover levels recognize in them more utilitarian value and more economic value, as well as more inputs for their activities. This finding contradicts the landuse conflict in the case study described above: nature conservation vs. economic development. Streams with higher vegetation cover, which is a positive factor contributing to the ecological status of streams from an ecological point of view, are regarded by landholders as inputs for their economic activities. As these comprise mainly farming, cattle, tourism, and sport hunting, activities that take advantage of the riparian forests of streams, the relationship makes sense.

High correlation coefficients (R) between the number of lost use values and the QBR total score and total riparian cover (Table 2), combined with the correlations discussed above, suggest that some of the features of streams that were valued in a utilitarian way in the past are still valued nowadays independently of the transition of stream uses presented in the previous section, which is an interesting aspect to be explored in further research.

Another interesting relationship is the correlation between the number of use values and the $\mathrm{NH}_{4}{ }^{+}$ content in the moss (Table 2): the higher the levels of $\mathrm{NH}_{4}{ }^{+}$in the water, the lower the values recognized for the corresponding stretch of river. Ammonium is a pollutant indicator of eutrophication and $\mathrm{N}$ enrichment in streams. It is important to note, however, that due to the low number of sampling for $\mathrm{NH}_{4}^{+}$levels $(N=9)$, further research is required before conclusions can be drawn about this relationship. This trend is nevertheless interesting.

Finally, correlations also indicate that an increase in As contamination is significantly related to an increase in the number of identified lost use values. Because previous studies in the area (Branquinho et al. 2007) showed a relationship between the concentration of As in mosses and the areas of pasture and the number of cow equivalents on the property, the relationship found now is in line with the transition of uses shown in the previous section. Arsenic contamination has been also connected to cattle in other contexts, particularly through the use of disinfectant compounds for ticks and other pests (Smith et al. 2003).

\section{Human Shaping of Streams}

In order to characterize landholders' stated practices regarding stream management, frequency of the practices surveyed in the interviews is shown in Table 3.

Results clearly show that the major interventions of landholders in streams are linked to: (i) the removal of vegetation and human garbage from the stream 
Fig. 2. Categories of use values, lost use values, non-use values, and lost non-use values of the streams identified by the 32 landholders and corresponding frequency of value category being cited among the 32 landholders.

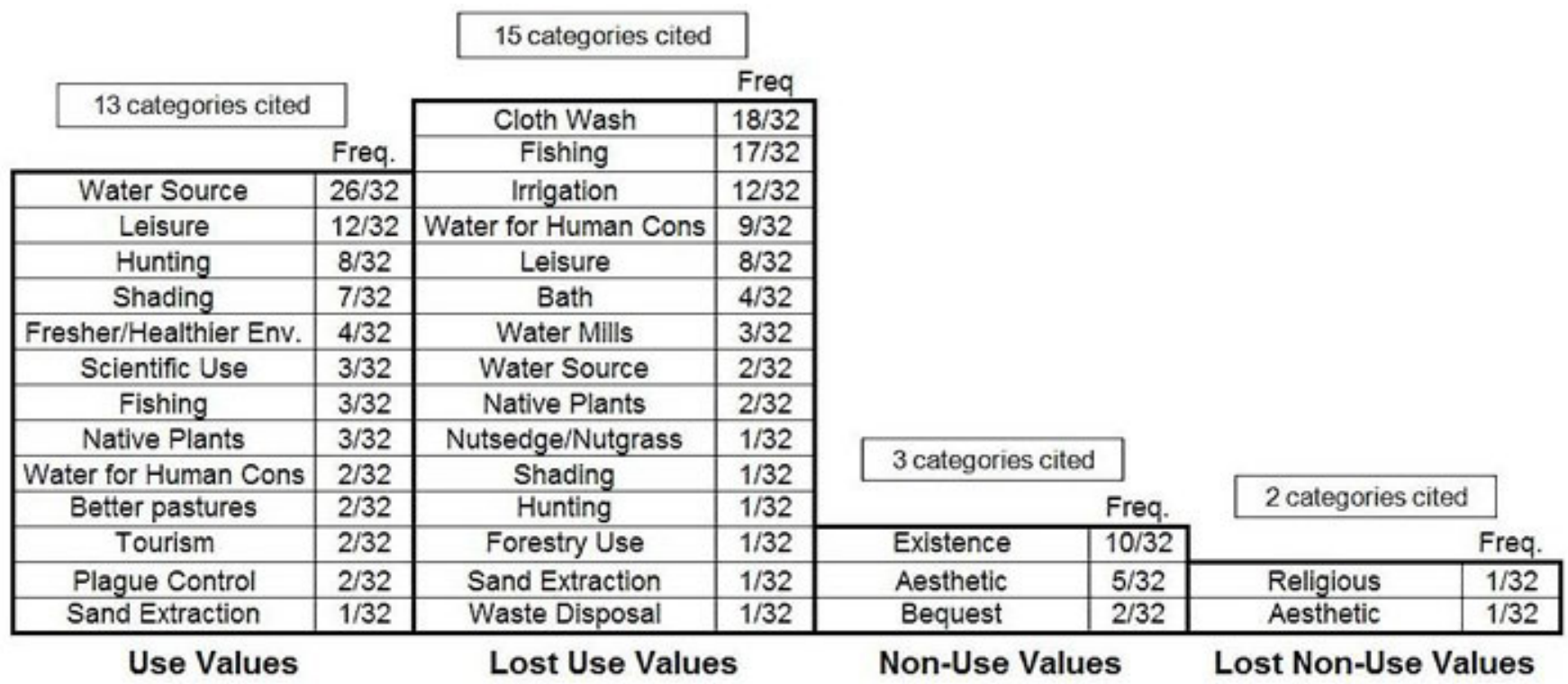

and (ii) the removal of shrubs from the stream margins, with $77.78 \%$ of interviewees who discussed practices on streams during their interview stating that these were done. In general, most people argued these two practices need to be done for three main reasons: (i) flooding prevention ("otherwise when water comes we have a problem (...) it accumulates and gets out of the waterway"); (ii) erosion prevention ("When the river level gets higher we lose soil"); (iii) waterway maintenance ("Leave streams clean of dirt present in the river bed"-dirt meaning either excess vegetation or garbage disposed in streams by other people).

Another important result is the number of interviewees who cited tree cutting as a practice: only $3.7 \%$, which contrasts greatly with the level of landholder intervention in the shrub stratum.

The way people intervene in the streams (manually, using machinery, or using chemicals) was not discussed in many interviews and, therefore, the results are not conclusive.

Many landholders expressed their dissatisfaction with neither being allowed by the administrative authorities to clean streams without a license (which costs money and must be presented as a project), nor having the authorities doing it periodically: "Many times! [the authorities don't clean smaller streams]"; "We would like to have it cleaned (...) but someone, if we intervene there, will prohibit and get us fines and whatever... (...) we cannot do anything there; (...)" "it's stupid to pay a license for something that contributes to the state."

\section{Landholders' Conceptualizations of Streams}

To understand why people manage stream vegetation the way they do, this section is devoted to an exploration of the different conceptualizations of streams emerging from the interviews.

The value of the tree stratum and microclimate created by riparian forests was highlighted by interviewees. Some sample statements are given below:

- Everything is cleaned, only trees are there now. And now it's even those trees that protect the rest, blackberry is gone. All gone. 
Fig. 3. Stream use by local people over time: past and present values of streams identified by the 32 landholders.

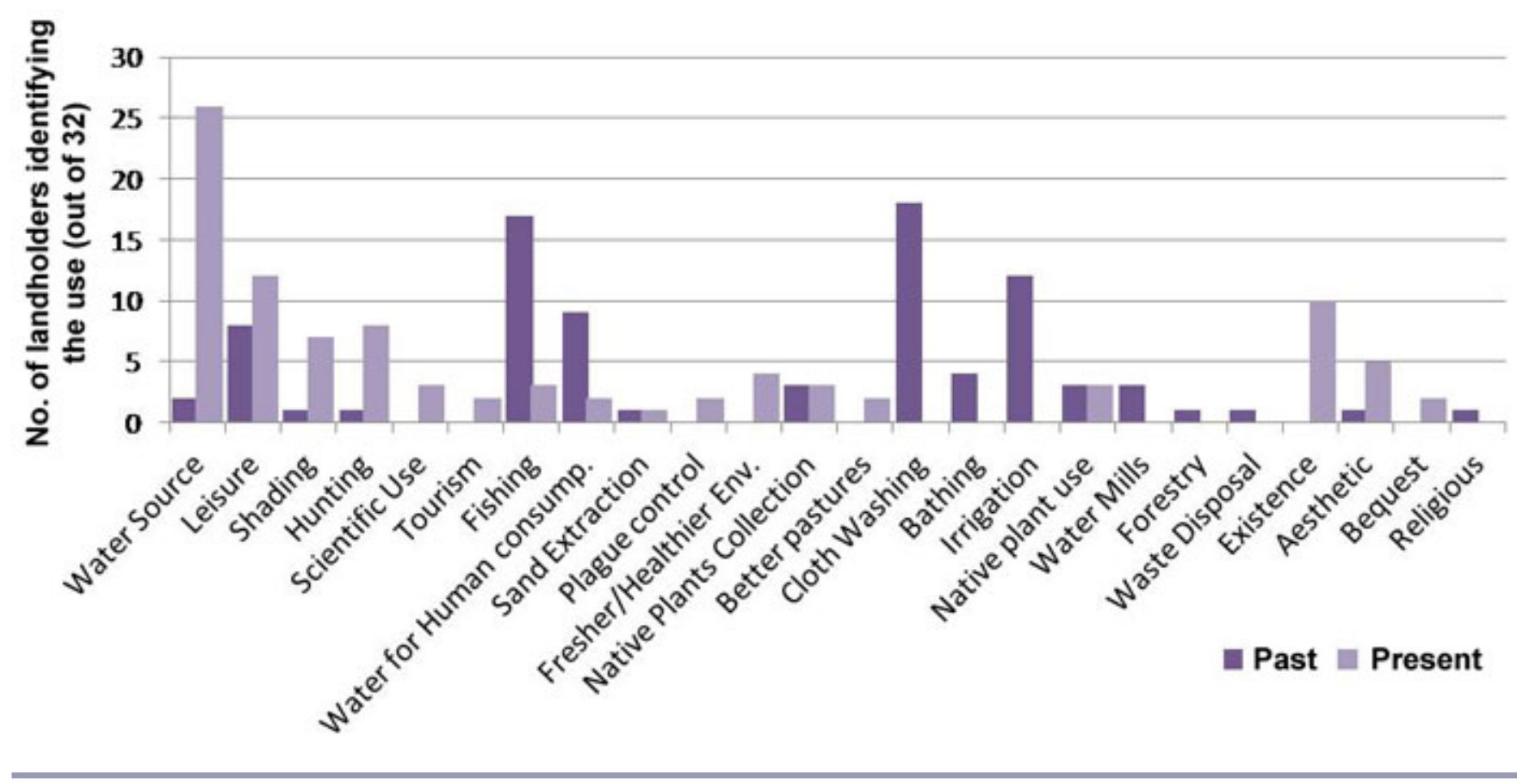

It just stays what gives beauty to the stream, which are trees that were planted. Alders, ashes, sessile oaks, and all those things I planted.

- The trees let them stay. (...) No, the trees are all good. It's the poplar. The cork oak. The holm oak. There are a lot of those trees by the stream. That you cannot destroy, it is no prejudice. The poplar, the ash... The ash, the alder and the poplar. Yes, take it all [giant reeds and blackberry]. The trees we never take them out.

- This is mostly bay laurels and ashes [around the stream]. The elms are all gone. And plane trees, and also plane trees. (...) Here it is a wood, that's what it is. (...) There it was all elms. It was a disease; all got dried from a moment to the other. The ashes stayed, we have a lot of ashes there and we are still putting them on the creeks. (...) It's a microclimate. This in the old times, with those huge trees, this was even better then(...).
- It's an area where we feel better the importance of water than in other areas (...) it's an area that has special characteristics and is greener than any other area, even the type of vegetation. It's not only the cork oak or the holm oak; instead there are a funny variety of trees. It's an area, I would say, semi-wet. So it is very rich in terms of quality and variety of pastures and very rich at the tree level. (...) S. Cristóvão stream to me has a landscape and environmental value and everything... to me is one of the most beautiful areas in this region here. An area greener, more beautiful, richer. (...) you can find ashes, poplars, alders, etc.

At the same time, more negative attitudes regarding the shrub stratum are also apparent:

- [About the excess of boars on the property] because a ditch full of blackberry all over results in that. (...) [if it would be better to take out the blackberry] Yes! At least the animals wouldn't come... (...) We have small sheep here(...). 
Table 2. Correlation between (i) ecological indicators: concentration of the following elements measured in the mosses: copper $(\mathrm{Cu})(\mu \mathrm{g} / \mathrm{g} \mathrm{DW})$, zinc $(\mathrm{Zn})(\mu \mathrm{g} / \mathrm{g} \mathrm{DW})$, manganese $(\mathrm{Mn})(\mu \mathrm{g} / \mathrm{g} \mathrm{DW})$, iron $(\mathrm{Fe})(\mu \mathrm{g} /$ $\mathrm{g} \mathrm{DW})$, lead $(\mathrm{Pb})(\mu \mathrm{g} / \mathrm{g} \mathrm{DW})$, nickel (Ni) $(\mu \mathrm{g} / \mathrm{g} \mathrm{DW})$, arsenic (As) $(\mu \mathrm{g} / \mathrm{g} \mathrm{DW})$, total nitrogen $(\mathrm{N})(\% / \mathrm{DW})$, the ratio between total carbon and total nitrogen $(\mathrm{C}: \mathrm{N})$, ammonium $\left(\mathrm{NH}_{4}^{+}\right)(\mu \mathrm{g} / \mathrm{g} \mathrm{DW})$; vitality indicator of the mosses measured by Fv/Fm in relation to the control per season (\%); and the QBR index total score $(\mathrm{QBR}$ Total $-\%)$ and its four components $(\mathrm{TRC}=$ total riparian cover, $\mathrm{CS}=$ cover structure, $\mathrm{CQ}=\mathrm{cover}$ quality, and $\mathrm{CA}=$ channel alteration; ranging from 0-25\%); and (ii) surveyed values of the streams, identified by the 32 landholders interviewed: number of use values (lost and current), non-use values (lost and current) and economic values (considered water for cattle, shading for cattle, irrigation, rural tourism, and hunting renting contracts). The values shown in the table are for Pearson correlation coefficients $(R)$ and for the levels of significance $(p)$. Correlations marked in bold are significant at $p<0.05$.

\begin{tabular}{|c|c|c|c|c|c|c|c|c|c|c|c|}
\hline & \multirow[t]{2}{*}{$\mathrm{N}$} & \multicolumn{2}{|c|}{ No. Use Values } & \multicolumn{2}{|c|}{$\begin{array}{l}\text { No. Non-Use } \\
\text { Values }\end{array}$} & \multicolumn{2}{|c|}{$\begin{array}{l}\text { No. Lost Use } \\
\text { Values }\end{array}$} & \multicolumn{2}{|c|}{$\begin{array}{l}\text { No. Lost Non- } \\
\text { Use Values }\end{array}$} & \multicolumn{2}{|c|}{$\begin{array}{c}\text { Economic Use } \\
\text { Values }\end{array}$} \\
\hline & & $\begin{array}{c}\text { Pearson } \\
\quad R\end{array}$ & $p$-level & $\begin{array}{c}\text { Pearson } \\
R\end{array}$ & $p$-level & $\begin{array}{c}\text { Pearson } \\
\quad R\end{array}$ & $p$-level & $\begin{array}{c}\text { Pearson } \\
R\end{array}$ & $p$-level & $\begin{array}{c}\text { Pearson } \\
\quad R\end{array}$ & $p$-level \\
\hline $\mathrm{Cu}(\mu \mathrm{g} / \mathrm{g} \mathrm{DW})^{\mathrm{a}}$ & 37 & -0.2429 & 0.147 & 0.1318 & 0.432 & -0.0952 & 0.575 & -0.1276 & 0.452 & -0.2419 & 0.149 \\
\hline $\mathrm{Zn}(\mu \mathrm{g} / \mathrm{g} \mathrm{DW})^{\mathrm{a}}$ & 37 & -0.2444 & 0.145 & -0.0872 & 0.608 & -0.0609 & 0.720 & -0.0449 & 0.792 & -0.1170 & 0.490 \\
\hline $\operatorname{Mn}(\mu \mathrm{g} / \mathrm{g} D W)^{a}$ & 35 & -0.0520 & 0.767 & 0.0771 & 0.660 & -0.2624 & 0.128 & -0.2123 & 0.221 & -0.2641 & 0.125 \\
\hline $\mathrm{Fe}(\mu \mathrm{g} / \mathrm{g} \mathrm{DW})^{\mathrm{a}}$ & 36 & -0.1427 & 0.406 & 0.0675 & 0.696 & -0.0262 & 0.879 & -0.0283 & 0.870 & -0.1267 & 0.461 \\
\hline $\mathrm{Pb}(\mu \mathrm{g} / \mathrm{g} \mathrm{DW})^{\mathrm{a}}$ & 35 & -0.2830 & 0.100 & -0.1297 & 0.458 & -0.2365 & 0.171 & -0.2016 & 0.245 & -0.1842 & 0.289 \\
\hline $\mathrm{Ni}(\mu \mathrm{g} / \mathrm{g} \mathrm{DW})^{\mathrm{a}}$ & 8 & -0.4875 & 0.220 & 0.1712 & 0.685 & 0.1298 & 0.759 & - & - & -0.6540 & 0.079 \\
\hline As $(\mu \mathrm{g} / \mathrm{g} \mathrm{DW})^{\mathrm{a}}$ & 37 & -0.0720 & 0.672 & 0.2499 & 0.136 & 0.5110 & 0.001 & 0.1184 & 0.485 & -0.0069 & 0.968 \\
\hline $\mathrm{N}(\% / \mathrm{DW})^{\mathrm{a}}$ & 37 & 0.0853 & 0.616 & 0.0615 & 0.718 & -0.0495 & 0.771 & -0.1729 & 0.306 & 0.0945 & 0.578 \\
\hline $\mathrm{C}: \mathrm{N}^{\mathrm{a}}$ & 37 & 0.1905 & 0.259 & 0.0552 & 0.745 & 0.0749 & 0.659 & 0.0139 & 0.935 & 0.1580 & 0.350 \\
\hline $\mathrm{NH}_{4}^{+}(\mu \mathrm{g} / \mathrm{g} \mathrm{DW})^{\mathrm{b}}$ & 9 & -0.7610 & 0.017 & -0.1783 & 0.646 & -0.0775 & 0.843 & - & - & -0.6675 & 0.049 \\
\hline $\mathrm{Fv} / \mathrm{Fm}(\%)^{\mathrm{a}}$ & 35 & 0.0144 & 0.935 & 0.1557 & 0.372 & -0.0516 & 0.768 & 0.0448 & 0.798 & 0.0361 & 0.837 \\
\hline QBR Total $(\%)^{\mathrm{c}}$ & 36 & 0.3837 & 0.021 & 0.0683 & 0.692 & 0.3939 & 0.017 & 0.2512 & 0.139 & 0.4646 & 0.004 \\
\hline $\operatorname{TRC}(0-25 \%)^{\mathrm{c}}$ & 36 & 0.5399 & 0.001 & 0.1542 & 0.369 & 0.3713 & 0.026 & 0.2706 & 0.110 & 0.6378 & 0.000 \\
\hline $\operatorname{CS}(0-25 \%)^{\mathrm{c}}$ & 36 & 0.4466 & 0.006 & 0.1688 & 0.325 & 0.2408 & 0.157 & 0.0474 & 0.784 & 0.3849 & 0.020 \\
\hline $\mathrm{CQ}(0-25 \%)^{\mathrm{c}}$ & 36 & 0.1077 & 0.532 & 0.0831 & 0.630 & 0.3275 & 0.051 & 0.1807 & 0.292 & 0.2366 & 0.165 \\
\hline $\mathrm{CA}(0-25 \%)^{\mathrm{c}}$ & 36 & -0.1375 & 0.424 & -0.3043 & 0.071 & 0.0597 & 0.729 & 0.1574 & 0.359 & -0.1129 & 0.512 \\
\hline
\end{tabular}

${ }^{a}$ average values for the time period from September 2004 to June 2005.

${ }^{\mathrm{b}}$ values assessed from March to June 2005.

${ }^{c}$ values assessed from March to June 2006.

Marked correlations in bold are significant at $p<0.05$ 
Fig. 4. Relationship between (i) total riparian cover (the proportion of established vegetation that exists in the margins: shrubs and trees, a sub-component of QBR ranging from 0-25\%) and (ii) the number of use values identified by the landholder of the corresponding stream (left) and the number of economic use values identified by them (right, considered: water for cattle, shading for cattle, irrigation, rural tourism, and hunting renting contracts). $N=36$.
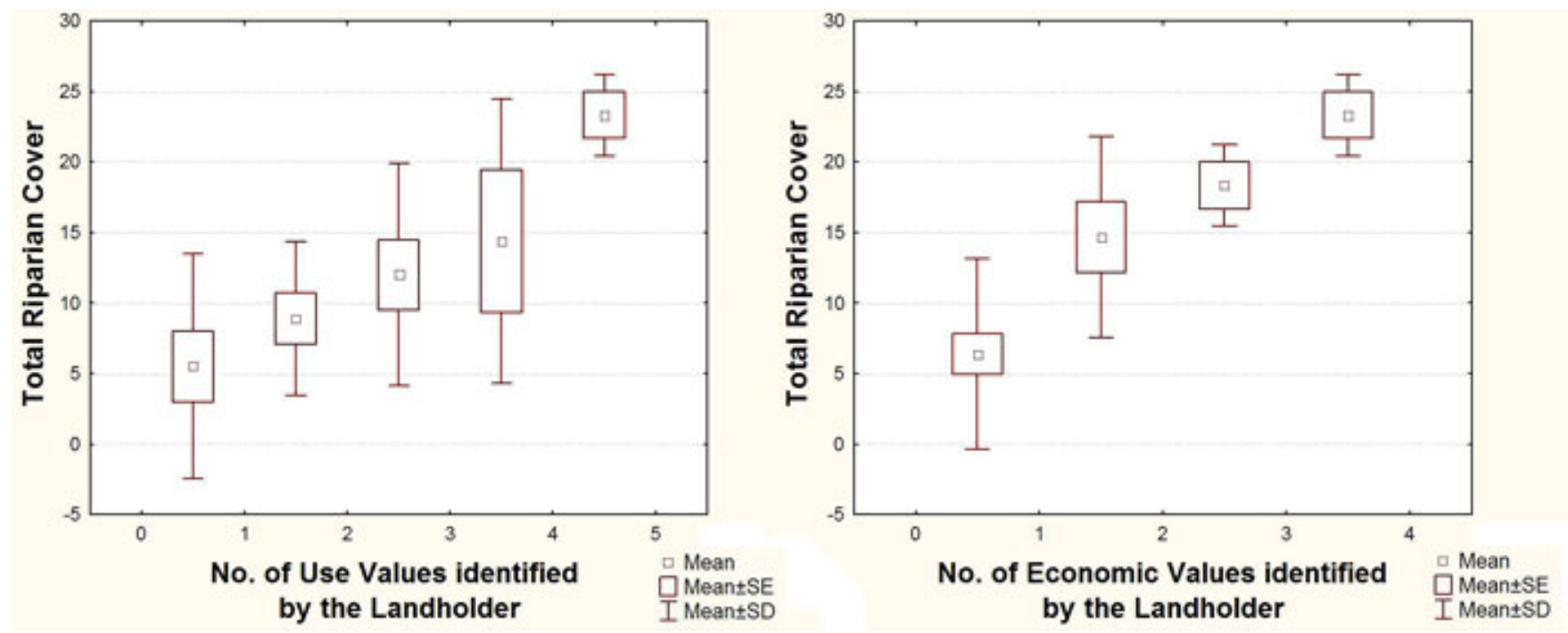

- Both animals and people like water, like rivers. Specially being a cleaned stream (...) our stream is not cleaned, it's shrubs everywhere, garbage...;

- But that one there [stream]... It's just blackberry all over, willows, all the rubbish there is;

- This stream has very little significance because most of the year it's dry. (...) because of shrubs and those things we cleaned it and continue cleaning in order to have the waterway in good condition, right?

The high value given to the tree stratum is in accordance with previous literature. Kenwick et al. (2009) found that for both planners and residents tree buffers earned the highest preferences out of various buffer types in riparian areas, in both rural and suburban settings of counties in the midwestern United Sates. It is also in accordance with several values and uses identified in previous sections, from aesthetics to microclimate and shading, for example.

The reasons for the devaluation of the shrub stratum could be diverse. In the previous section, it was presented and discussed that shrub removal is meant to prevent flooding and erosion, and keep the waterway in good condition. This devaluation could also have a cultural factor linked to the aesthetics of the surrounding landscape-the montadowhich is the agro-silvopastoral landscape dominant in the region over several generations. Montado is a savannah-like landscape, dominated by evergreen trees (cork oak and holm oak) and shaped by man over centuries of traditional land-use practices. These traditional practices (grazing and regular ploughing) interfere with the establishment of a shrub stratum, leaving it little developed or nonexistent. Moreover, as the statements above suggest, the shrub stratum in streams might be associated with an increased exposure of farm animals to native predators and wild animals such as boars, Egyptian mongooses or foxes, which can then reach the farm more easily. 
Table 3. Frequency of landholders' stated practices in stream management. The table shows the frequency of each practice (identified by landholders) as well as the number $(N)$ of interviews that provided valid information about that practice, from the 32 interviews done.

\begin{tabular}{lcc}
\hline \hline & Frequency $(\%)$ & $N$ \\
\hline Cuts trees & 3.70 & 27 \\
Cuts shrubs & 77.78 & 27 \\
Plants trees & 3.70 & 27 \\
Plants shrubs & 0.00 & 27 \\
Removes veg. litter and/or human garbage & 77.78 & 27 \\
Removes sediments & 11.11 & 27 \\
Margin stabilization & 3.57 & 28 \\
Closes the stream with fences & 11.11 & 27 \\
Discharges effluents in the stream & 3.45 & 29 \\
& & 18 \\
Manually & 16.67 & 18 \\
Using machinery & 61.11 & 19 \\
Using chemicals & 15.79 & 29 \\
States it as being done by him & & 29 \\
States it as being done by third party & 55.17 & 29.69 \\
\hline
\end{tabular}

A table with the full citations found for describing landholders' conceptualizations of streams is in Appendix 2, in which it is possible to identify the importance of two main hydrologic functions: the drainage capacity of the stream, and the stream as a source of water. These hydrologic functions, together with the cited aspects of riparian vegetation cover, were the two central ideas in the conceptualization of streams arising from the interviews.

\section{Human-Nature Relationship in Monfurado Streams and Water Management}

The study analyzed the human-nature relationship in Mediterranean streams through the characterization of the ecological status and the social role of streams and their linkages and interactions, in a context of land-use conflict between conservation and farming. It searches for key features in the interaction between social and ecological dimensions that could aid natural resource management by combining methodologies from the 
natural sciences and from the social sciences and integrating landholders' and experts' knowledge.

Interactions between social and ecological dimensions were shown to be important, which is in accordance with previous studies, e.g., Settle et al. (2002), who show that a model that integrates ecosystems and economic systems considering the bidirectional relationship between them provides a better analysis and prediction of ecological impacts from human actions than a model that ignores them.

Overall, the analysis revealed that riparian vegetation cover has a central and structural role in the human-nature relationship in Mediterranean streams of Monfurado, as is shown by the Results, and might, therefore, have an important role in improving management. At the same time, vegetation cover (i) is structural for ecological status and resilience of streams and is fundamental for microclimate, contributing to ecological functions of habitat, humidity and temperature regulation, ecological corridors, sink, source, filter and barrier (FISRWG 1998); (ii) scarcely exists along many streams according to the integrity biotic index used, but is structurally and qualitatively in satisfactory ecological status where it exists (Table 1); (iii) might be linked with pollutants found in significant quantities in surface water such as $\mathrm{Fe}, \mathrm{Mn}, \mathrm{Cu}, \mathrm{As}$, $\mathrm{NH}_{4}{ }^{+}$and the C:N ratio (Table 1); (iv) is an important input for economic activities of the area-wellestablished vegetation cover (tree and shrub strata) is of utilitarian and economic advantage (Figs. 2 and 4); (v) is promoted, at the tree stratum level, from the landscape, well-being, and aesthetic points of view of landholders (Appendix 2); and (vi) is not directly threatened by landholders' stated management practices on the streams at the level of the tree stratum, but is threatened, however, at the level of the shrub stratum (Table 3), as is confirmed by the riparian vegetation status (Table 1).

The IBI revealed that total riparian cover was the weakest feature in terms of the streams' ecological conservation status, making it evident riparian vegetation cover is scarce in many streams, but is structurally and qualitatively in satisfactory ecological status where it exists (Table 1). This might result in a diminution of the filtering capacity of in-flowing water by the streams. This contributes to the presence of pollutants in the water such as Fe, $\mathrm{Mn}$, and $\mathrm{Zn}$, which were significant and correlated to run-off and sediments. It also contributes to $\mathrm{Cu}$,
As, $\mathrm{NH}_{4}{ }^{+}$, and the $\mathrm{C}: \mathrm{N}$ ratio, which are significant and correlated to land use around the streams, as discussed in the first section.

There was a transition in the use of rivers, which previously addressed mainly basic needs like food provision (fish and water for human consumption) and personal hygiene, and is contemporaneously mostly connected to current economic activities (microclimate protection in the summer and source of water for extensive livestock production; sport hunting) (Figs. 2, 3). The results identified important economic uses of streams that are connected to important ecological features of streams, like riparian forests, which are used for shade and microclimate, which protects cattle during the summer.

The relationship found between total riparian cover and the number of utilitarian values and particularly economic ones (Fig. 4; Table 2) is very interesting for improving management. It may work as a conciliation point between conservation and economic development once features of the ecosystem that both perspectives would have interest in preserving are identified.

Established riparian forests correspond to high levels of total riparian cover (although the opposite is not necessarily true) and assume a central and important dimension throughout the study of the human-nature relationship. The previous section showed that landholders' conceptualization of streams is deeply linked with riparian forests: they particularly favor the tree stratum and also the microclimate created by these forests, but do not value the shrub stratum. The reasons for this devaluation were discussed in the previous section and may range from aesthetic factors to associating the shrub stratum with flooding, providing wild animals with access to farms, and erosion.

Although the lack of value given to shrubs does not agree with the concepts and ideals about streams issuing from ecology and from conservationists (FISRWG 1998), the value given to the stream stratum and the importance of microclimate created by riparian forests is recognized by landholders and coincides with those concepts and ideals. Furthermore, trees are almost unaffected by landholders' stated practices on streams (Table 3), substantiating this concordance and the above suggestion of a conciliation point. The shrub stratum 
—highly modified and devalued by landholders, but at the same time of conservation and ecological value-would, however, represent a conflict point.

In this way, overall, total riparian cover assumes a key structure role in social-ecological riparian systems management in Monfurado to be further developed. It provides a potential conciliation point at the tree stratum management level and an evident conflict point at the shrub stratum management level in the conflict of uses mentioned.

As in the case study, the implementation of conservation efforts in an area frequently requires adaptation from remaining land uses, often highlighting conflicts among users as a result. These conflicts, widely addressed by NGOs, and scientific and state institutions, may result in unsuccessful implementation of conservation plans.

The answer to these situations could be a process of social learning where existing knowledge and practices from all users are expressed and shared and where new knowledge, practices, motivations, and values are allowed to emerge collectively, resulting in a common and coherent strategy in the transition toward better management (currently, different actors in the case study are working in different directions). This approach ties in with the promotion of collaborative strategies widely addressed by the literature, which Nkhata et al. (2008) emphasize and propose as a means of addressing problems in the scope of socialecological systems, paying attention to the need for social actors to work together to enhance the capacity of social-ecological systems to cope with intermittent shocks.

In this context, the stated finding about the potential role of total riparian cover is of great value for management, as it represents a base for dialog, either mediated or direct, between different perspectives with their own motivations, values, and practices, sometimes concordant, sometimes not. Dialogs have been shown to be important for establishing social learning in participatory constructions (Nielsen and Nielsen 2006). The current study pointed out the basis for dialog; in a further perspective, the dialog could become a point of departure for continuous participatory social learning with a long-term democratic perspective for natural resource management framed in a coevolutionary approach to social-ecological systems.
The long-term perspective being introduced conforms to the idea that sustainability cannot be a static objective (Rammel et al. 2007), instead, sustainable development is an open evolutionary process of improving the management of socialecological systems through trust building and knowledge. It must be considered in the long run and at a relatively deep level of change in society. Nkhata et al. (2008) have underlined that most studies adopting collaborative strategies to address problems in social-ecological systems, with a few exceptions, have not given explicit attention to the changing nature of long-term social relationships.

\section{CONCLUSION}

This research studied the human-nature relationship in Mediterranean streams as a way to address the need to focus on social-ecological interactions and local knowledge. Its main objective was to improve the understanding of Mediterranean streams and, at the same time, to provide practical inputs to enhance local-level management through the cited analysis. By doing so, the study also intended to illustrate that an effort to diminish disciplinary-sector and knowledge-type boundaries benefits natural resource management.

Results characterized the connected systems from both the ecological and social points of view, which helped identify priority targets for management. It also characterized the relationship between both dimensions. The analysis identified a key structural element in the human-nature aggregate of Mediterranean streams in the Monfurado region: well-established riparian vegetation cover. This improves levels of knowledge about the humannature relationship and contributes to natural resource management, as this structure might have a central role in the dialog between the conflicting land uses discussed.

The advantage of focusing on the human-nature relationship in the analysis was to enhance the understanding of underlying processes of equilibrium in coupled social-ecological systems by looking at the interactions from the perspective of the whole. Concluding that well-established riparian cover is a key structural element illustrates this and was enabled by the theoretical approach. Interactions between social and ecological dimensions were shown to be important and contributed greatly to the findings. 
The findings were clearly supported by the integration of different types of knowledge. Combining natural and social sciences and experts' and lay people's knowledge contributed to a better understanding of processes in social-ecological systems. It was possible to realize that adopting a practice-oriented natural resource management perspective facilitates transdisciplinary integration. This was a major finding of this study. Furthermore, the combination of qualitative and quantitative information was relevant to understand reality more consistently, as it allows the analysis to cover different aspects of it.

Although the primary focus of the study was on exploring the contributions from the human-nature relationship analysis and the interactions between social and ecological dimensions, it is also important to stress that the adoption of different disciplinary perspectives and methodologies in the analysis allowed some depth and detail in the assessment and study of each part of the system as well.

The work has produced information with potential for future management of Mediterranean streams of the Natura 2000 Network, particularly regarding the conciliation of farming and conservation. Results have shown that there are common interests between the two groups, and there may be less antagonism than initially thought. This finding highlights the importance of sharing agendas between environmental and agricultural sectors as a strategy in natural resource management.

Further dialog between these groups from a socialchange perspective is signaled as having potential to improve natural resource management. Among the most important conclusions of the study is the need to consider social change in order to improve natural resource management in the area. This suggests that social change and environmental management may often be fundamentally linked, which is a great challenge to applied environmental sciences.

The involvement of landholders in the work was very positive. It markedly incorporated an enormous amount of knowledge and visions that would otherwise be inaccessible, and it identified a basis for dialog, out of which a point of departure for the referred social change may arise. Availability to listen and to dedicate time to this task is crucial for its success.

Finally, the value of specific human-nature interactions' diversity over space should be emphasized-it enforces resilience and adaptive capacity in a changing world context; it should be preserved.

Responses to this article can be read online at: http://www.ecologyandsociety.org/voll4/iss2/art35/ responses/

\section{Acknowledgments:}

This research was funded by LIFE 03 Nat/P/000018, PPCDT/AMB/63160/2004, FEDER POCI 2010 POCI/AMB/63160/2004, and FCT/MCTES SFRH/ BD/22096/2005. I thank Nuno Leandro for his important support in the interviewing process and the friends and colleagues who reviewed the paper or parts of it and who contributed to the datacollection process. I also thank György Pataki for his comments on the paper. Finally, I want to thank the landholders interviewed, who were in general honestly dedicated to sharing their ideas and, therefore, contributed largely to the products of this research.

\section{LITERATURE CITED}

Antunes, P., and R. Santos. 1999. Integrated environmental management of the oceans. Ecological Economics 31:215-226.

Argent, R., R. Grayson, and S. Ewing. 1999. Integrated models for environmental management: issues of process and design. Environment International 25(6-7):693-699.

Ballard, H. L., M. E. Fernandez-Gimenez, and V. E. Sturtevant. 2008. Integration of local ecological knowledge and conventional science: a study of seven community-based forestry organizations in the USA. Ecology and Society 13 (2): 37. [online] URL: http://www.ecologyandsociety. org/vol13/iss2/art37/. 
Blondel, J. 2006. The "design" of mediterranean landscapes: a millennial story of humans and ecological systems during the historic period. Human Ecology 34(5):713-729.

Branquinho, C., D. H. Brown, C. Máguas, and F. Catarino. 1997. $\mathrm{Pb}$ uptake and its effects on membrane integrity and chlorophyll fluorescence in different lichen species. Environmental and Experimental Botany 37:95-105.

Branquinho, C., C. Gonzalez, and M.A. MartinsLoução. 2007. Relatório Final GAPS-Gestão Activa e Participada do Sítio de Monfurado (LIFE03/NAT/P/000008) CEBV-FCUL / Acção D4. Centro de Ecologia e Biologia Vegetal, Faculty of Science, University of Lisbon, Lison, Portugal. [online] URL: http://www.cm-montemornovo.pt/w wwGAPS/RF-D4.pdf.

Cenci, R. M. 2000. The use of aquatic moss (Fontinalis antipyretica) as monitor of contamination in standing and running waters: limits and advantages. Journal of Limnology 60(Suppl. 1):5361.

Donovan, D. G., and R. K. Puri. 2004. Learning from traditional knowledge of non-timber forest products: Penan Benalui and the autecology of Aquilaria in Indonesian Borneo. Ecology and Society 9(3): 3. [online] URL: http://www.ecologya ndsociety.org/vol9/iss3/art3.

Duraiappah, A. 2002. Sectoral dynamics and natural resource management. Journal of Economic Dynamics and Control 26:1481-1498.

Ferreira, M. T., P. M. Rodríguez-González, F. C. Aguiar, and A. Albuquerque. 2005. Assessing biotic integrity in Iberian rivers: development of a multimetric plant index. Ecological Indicators 5:137-149.

Fielding, K. S., D. J. Terry, B. M. Masser, P. Bordia, and M. A. Hogg. 2005. Explaining landholders' decisions about riparian zone management: the role of behavioural, normative, and control beliefs. Journal of Environmental Management 77:12-21.

Figueira, R. 2002. Desenvolvimento de um sistema de biomonitorização ambiental. Dissertation, Faculty of Science, University of Lisbon, Lisbon, Portugal.
Federal Interagency Stream Restoration Working Group (FISRWG), editors. 1998. Stream corridor restoration: principles, processes and practices. Vol. GPO Item No. 0120-A; SuDocs No. A 57.6/2: EN 3/PT.653. FISRWG (15 federal agencies of the U.S. government). [online] URL: http://www.nrcs. usda.gov/technical/stream restoration/.

Gasith, A., and V. H. Resh. 1999. Streams in Mediterranean climate regions: abiotic influences and biotic responses to predictable seasonal events. Annual Review of Ecological Systems 30:51-81.

International Union for Conservation of Nature (IUCN). 1998. Economic values of protected areas: guidelines for protected area managers. IUCN, Gland, Switzerland and Cambridge, UK.

Kallis, G. 2007. When is it coevolution? Ecological Economics 62:1-6.

Kenwick, R. A., M. R. Shammin, and W. C. Sullivan. 2009. Preferences for riparian buffers. Landscape and Urban Planning, in press.

Kessler, C.A. 2007. Motivating farmers for soil and water conservation: a promising strategy from the Bolivian mountain valleys. Land Use Policy 24:118-128.

Martins, R. J. E., R. Pardo, and R. A. R. Boaventura. 2004. Cadmium (II) and zinc (II) adsorption by the aquatic moss Fontinalis antipyretica: effect of temperature, $\mathrm{pH}$ and water hardness. Water Research 38:693-699.

Mersch, J., and M. Reichard. 1997. In situ investigation of trace metal availability in industrial effluents using transplanted aquatic mosses. Archives of Environmental Contamination and Toxicology 34:336-342.

Miller, S. J., D. H. Wardrop, W. M. Mahaney, and R. P.Brooks. 2006. A plant-based index of biological integrity (IBI) for headwater wetlands in central Pennsylvania. Ecological Indicators 6 (2):290-312.

Moller, H., F. Berkes, P. O. B. Lyver, and M. Kislalioglu. 2004. Combining science and traditional ecological knowledge: monitoring populations for co-management. Ecology and Society 9(3): 2. [online] URL: http://www.ecologya ndsociety.org/vol9/iss3/art2. 
Munné, A., N. Prat, C. Solà, N. Bonada, and M. Rieradevall. 2003. A simple field method for assessing the ecological quality of riparian habitat in rivers and streams: QBR index. Aquatic Conservation: Marine and Freshwater Ecosystems 13:147-163.

Nielsen, K. A., and B. S. Nielsen. 2006. Methodologies in action research. Pages 63-88 in K. Aagaard Nielsen, and L. Svensson, editors. Action research and interactive research. Shaker Publishing, Maasstricht, The Netherlands.

Nkhata, A. B., C. M. Breen, and W. A. Freimund. 2008. Resilient social relationships and collaboration in the management of social-ecological systems. Ecology and Society 13(1): 2. [online] URL: http:// www.ecologyandsociety.org/vol13/iss1/art2/.

Pereira, H. M., T. Domingos, and L. Vicente. 2004. Portugal millennium ecosystem assessment: state of the assessment report. Centro de Biologia Ambiental, Faculdade de Ciências da Universidade de Lisboa, Lisbon, Portugal. [online] URL: http://w ww.millenniumassessment.org/documents sga/Portugal\% 20MA State of the Assessment.pdf.

Pope, J., D. Annandale, and A. MorrisonSaunders. 2004. Conceptualising sustainability assessment. Environmental Impact Assessment Review 24:595-616.

Pratschke, J. 2003. Realistic models? Critical realism and statistical models in the social sciences. Philosophica 71:13-38.

QSR. 2008. QSR NVivo Version 8.0.264.0 SP3. QSR International Pty Ltd. 1999-2008.

Rammel, C., S. Stagl, and H. Wilfing. 2007. Managing complex adaptive systems - a coevolutionary perspective on natural resource management. Ecological Economics 63:9-21.

Reiss, K. C. 2006. Florida wetland condition index for depressional forested wetlands. Ecological Indicators 6(2):337-352.

Rietbergen-McCracken, J., and H. Abaza. 2000. Environmental valuation. First edition. Earthscan Publications, London, UK.

Rotmans, J., and M. B. A. V. Asselt. 2001.
Uncertainty management in integrated assessment modeling: towards a pluralistic approach. Environmental Monitoring and Assessment 69:101-130.

Salinas, M. J., G. Blanca, and A. T. Romero. 2000. Riparian vegetation and water chemistry in a basin under semiarid Mediterranean climate, Andarax River, Spain. Environmental Management 26 (5):539-552.

Settle, C., T. D.Crocker, and J. F. Shogren. 2002. On the joint determination of biological and economic systems. Ecological Economics 42(12):301-311.

Silvano, R. A. M., S. Udvardy, M. Ceroni, and J. Farley. 2005. An ecological integrity assessment of a Brazilian Atlantic forest watershed based on surveys of stream health and local farmers' perceptions: implications for management. Ecological Economics 53(3):269-385.

Smith, E., J. Smith, L. Smith, T. Biswas, R. Correll, and R. Naidu. 2003. Arsenic in Australian environment: an overview. Journal of Environmental Science and Health, Part A 38(1):223-239. [online] URL: http://www.informaworld.com/smpp/section? content=a713630171\&fulltext=713240928.

SNIRH. 2008. National system of information on water resources. [online] URL: http://snirh.pt/snirh. php?main $\mathrm{id}=1$.

Spash, C. L., K. Urama, R. Burton, W. Kenyon, P. Shannon, and G. Hill. 2009. Motives behind willingness to pay for improving biodiversity in a water ecosystem: economics, ethics and social psychology. Ecological Economics 68(4):955-964.

van den Bergh, J., and P. Nijkamp. 1991. Operationalizing sustainable development: dynamic ecological economic models. Ecological Economics 4(1):11-33.

van der Ploeg, S., L. Braat, and W. van Lierop. 1987. Integration of resource economics and ecology. Ecological Modelling 38(1-2):171-190.

Vázquez, M. D., J. López, and A. Carballeira. 1999. Uptake of heavy metals to the extracellular and intracellular compartments in three species of aquatic bryophyte. Ecotoxicology and Environmental Safety 44:12-24. 
Xu, J., L. Chen, Y. Lu, and B. Fu. 2006. Local people's perceptions as decision support for protected area management in Wolong Biosphere Reserve, China. Journal of Environmental Management 78:362-372. 
APPENDIX 1. Check Catalog for landholders.

The interview is open and non-structured and is conducted by the interviewee after opening a line of conversation. The questions are not to be followed or done in this specific order or format, as long as the interviewee meets the Check Catalog systematized below. The questions serve as a guiding map and inspiration only. The interview is also a first contact to meet the person and hence it's very informal.

\section{Moderation/lines of conversation:}

\section{Identification}

Name:

Sampling point, Stream and Property:

Sex:

Age:

Study: a. Primary School b. Secondary c. Tertiary d. University e. Post-Grad

Profession:

Direct Contact:

$\underline{\text { Riparian Values and relationship with streams/water }}$

1. Do you like your stream? Why?

2. How do you live better, with or without stream? Why?

3. What do you use the stream for, and what do you like in it? Why? Why is the river good?

4. How was it used before? 30-50 years ago. Before did people use the river more, or less?

5. Would you prefer to not have the river in your property? Why?

6. What do you use water for in your property? And what are the sources?

\section{Environmental/Water Awareness}

1. Do you have any problems with water and streams? And in Portugal do you think there are any problems regarding this?

2. Do your neighbors have the same problems?

3. Do you think streams have environmental problems?

4. Is there lack of water? And Pollution? Why? And before, 30-50 years ago?

5. Was there anything done in this region at the environmental level?

6. Are you worried or have needs at any other levels? What are those worries or needs? Why do they exist? What can be done to change the situation? Is there anything you can do, what?

\section{Conflict, social dynamic and control perception}

1. Are any of the features you identified or valued in the stream getting lost? Why? 
2. Would you like that to be different? How could that be different?

3. Is there anything you can do to change it?

4. Is the conjoint management with neighbors difficult or problematic? How?

5. If so, what are the issues at stake? Are there conflicts? Why? And 30-50 years ago?

Preliminary survey of stakeholders and policies

1. Are you receiving any subsidy or funding? From which entity? How did you know about it?

2. Is the stream managed and cleaned or not? Who does it? How is it done? Why is it done that way?

3. Do you recommend anyone you think I should talk to about all these issues?

4. In this area who is managing water and streams? Who is interested in them? Who likes them and usufructs from their existence?

\section{$\underline{\text { Personal Profile }}$}

1. For how many years do you live or work here?

2. What area is this? To what village does it belong? Who's the owner? Is he from here?

3. Do you like to live here? And before, did you like to live here, more or less then nowadays?

4. Do you have any activities besides your work here? Do you work, even if sporadically, to any NGOs, Political parties, the church, cooperatives? Why do you do it or why not?

\section{Check Catalog:}

River Values

Attachment and Identity

II

III

IV
Use (monetary or not)

Non-use

Economic (monetary or not and markets existing)

Identity and Attachment

Cultural

Attachment to place Identity with lifestyle Attachment to the community Attachment to the stream: Water, Corridor, Stream structure, Flora, Fauna...

Value systems Proactivity and engagement: Activities for NGOs, political parties, church...

Ecological Functions: sink, conduction, filter, corridor, source, barrier, drainage

Features connected to:

- Water, volume e quality

- Corridor

- Stream Structure - artificial/natural

- Flora

- Fauna

- Impacts of Water Reservoirs 
Environmental worries in general Worries with stream and water conservation

Problems felt associated with water issues: scarcity, quality, superficial/ subterranean, which of the identified stream values are at risk Other worries and problems felt

VI Control Perception and stakeholder

People and institutions having interest in water and streams and institutional preliminary survey

Conflicts existing and their explanation and possible solutions The role of landholders in the solutions

Existing wrong signals in policy

VII Water and stream management

Who manages streams and how and for which purpose Practices of landholders on streams and their motivations

VIII Space: Administrative or Community belonging

Community to which they belong to

Region to which they belong to 


\section{APPENDIX 2. Conceptualizations of streams emerging from the interviews.}

"(...) the environment is healthier [by the stream], I mean, the shadow, the trees itself (...)"

"(...) If you buy a property, buy it by the river, with no pollution, it's better. We are better in the freshness of Poplars. You may have more mosquitoes, but well. (...)"

"(...) This stream has very little significance because most of the year it's dry. (...) because of shrubs and those things we cleaned it and continue cleaning in order to have the waterway in good condition right? (...)

"(...) This isn't even a stream, it's a creek. (...) the creek cannot disappear because the water has to go to some place. (...)"

"(...) [about the advantages of having the stream by the property] Water, sometimes I use it for irrigation for meadows. And shading. (...) For the animals and for us [the shading], because it refreshes a little bit the area which is very hot. I live there, I'm not really a farmer, and it's pretty (...)"

"(...) when there is a lot of water you also have it in the stream. (...) But to be a farmer it would be easier not to have the stream. (...)I think it is pretty [the riparian gallery] but it is also possible to plant it elsewhere, to substitute the trees that were there (...) When it is possible to clean and create a situation where people can see the water, yes [the riparian gallery brings benefits]. But this way, all dense, with trees, they don't usufruct. (...)"

“(...) they could be cleaner, but then too much cleaning also brings other problems. On that issue, let nature work. Here you have, look, I leave these willows. (...) I have a lot of trees there that... That poplar is not there by chance. There are already other smaller ones and I let them, exactly because this is so hot, in order to have a refreshing system. But I think that everything that is trees, whatever type they are... even willows, that are terrible, I protect them when little. (...) Now the bushes... There the stream is less... You should take out the bushes, just to make sure it doesn't stay in the way [of the water] when it's flooding, apart from that no one interferes with the stream. Just let nature work. (...) But streams on the other side, you shouldn't clean them too much because then the water itself digs and ruins the forest the stream has (...)"

"(...) Because the waters... It receives the waters, right? (...) Maybe it is convenient for us (...) Well yes, there were some people planting poplars, ashes, things like that, right? (...) I think it is good to have it cleaned so the water runs when it rains. (...)"

"(...) [about the excess of boars in the property] because a ditch full of blackberry all over results in that. (...) [if it would be better to take out the blackberry] Yes! At least the animals'wouldn't come... (...) We have small sheep here. (...)" 
"(...) And I love the stream for its vegetation. The stream never dries out. And for the quantity of wildlife existing in the stream. (...) [about the benefit of the stream] have green vegetation the whole year (...) I usually say that here I'm not in Alentejo, but instead on paradise. I have so much vegetation around. Although I like Alentejo very much, I usually say I'm on paradise because of the stream."

"(...) If it wasn't the stream, the water would get out of the stream (...) [about the reasons why a property has more value if it has a stream] Because of creeks, because of the water the property has, because of the land, for everything. The creeks are here because they are needed. And if they are! One more proof that the land is good. Because it has to be drained, you see? Otherwise it gets too wet. But if it gets too wet it's also because it can handle more humidity. (...)"

"(...) the stream there doesn't have enough shadow. (...) if the small stream would run the whole year that would be a paradise (...)"

"(...) it's an area where we feel better the importance of water than in other areas (...) it's an area that has special characteristics and is greener than any other area, even the type of vegetation. It's not only the cork oak or the holm oak; instead there are a funny variety of trees. It's an area, I would say, semi-wet. So it is very rich in terms of quality and variety of pastures and very rich at the tree level. (...) S. Cristóvão Stream to me has a landscape and environmental value and everything... to me is one of the most beautiful areas in this region here. An area greener, more beautiful, richer. (...) you can find Ashes, Poplars, Alders, etc... (...)"

"(...) [about a small stream that rarely has water] So it's like I'm telling you. This is water from the mountain passing here, on the other side of the mountain it passes there. I know it does. So, streams we can count as streams it's only the Alcáçovas stream [further downstream], there you have it... [meaning only there it has enough size to call it a stream, and not before]"

"(...) The stream here is for drainage, nothing else. (...) It is small, doesn't have... It's... basically... Here we call it a creek, we don't call it stream... Stream is where this one will empty into (...) It doesn't even have habitats, no bushes, nothing... no edges with bushes where other types of fauna could live in. It is dry in the summer, completely dry, too. (...) I don't think this is a stream like you understand it, right? (...) because here you don't have a stream with dimension, with habitat natural of certain species and stuff. Here there are no issues, because it is about small creeks, drainage ditches. Only that, nothing more. (...)"

"(...) at least it is a water current there [the stream] (...)"

"(...) The flow reduces [in the dry periods], but it always runs. But very good, very good. It has several springs along the waterway. (...)"

"(...) it always has water there (...)"

"(...) [about the benefits of the stream] to drain water (...) That stream there... Stream.... it is a creek! (...)" 
"(...) everybody likes to have creeks in their properties (...) if the creek is there it's because there is plenty of water. (...) The shadow, that's no longer from the stream, it's from the ashes. (..)"

"(...) There was no vegetation there. Not even cork oaks... They may have taken it out (...)"

"(...) you can't call this a stream. That is not a stream; it's a creek, a sort of ditch that exists there (...)"

"(...) It's just blackberry all over. (...) If the summer is very, very hot, it almost dries out. (...) And in the winter it gets out of the water way. (...) The stream is small. (...)"

"(...) The stream is all good. (...) But it needs to be clean. (...) of bushes. The water quality is good (...) In any property the stream is the defense of the property, it's a water [existing there]. (...)"

"(...) The trees let them stay. (...) No, the trees are all good (...). It's the poplar. The cork oak. The holm oak. There are a lot of those trees by the stream. That you cannot destroy, it is no prejudice. The poplar, the ash... The ash, the alder and the poplar. (...)"

"(...) Both animals and people like water, like rivers. Specially being a cleaned stream (...) Our stream is not cleaned, its shrubs everywhere, garbage... (...)"

"(...) This is mostly bay laurels and ashes [around the stream]. The elms are all gone. And plane trees, and also plane trees. (...) It's a microclimate. This in the old times, with those huge trees, this was even better then. (...)"

"(...) But that one there [stream]...It's just blackberry all over, willows, all the rubbish there is (...)"

"(...) Everything is cleaned, only trees are there now. And now it's even those trees that protect the rest, blackberry is gone. All gone. It just stays what gives beauty to the stream, which are trees that were planted. Alders, ashes, sessile oaks and all those things. I planted. (...)" 